\title{
NOTARIS PAILIT DALAM PERATURAN JABATAN NOTARIS
}

\author{
Galuh Puspaningrum ${ }^{1}$ \\ Fakultas Hukum Universitas Jember \\ Jln, Kalimantan Nomor. 37, Kampus Tegalboto, Jember, \\ Jawa Timur, 68121, Indonesia \\ Email : galuh.fh@unej.ac.id
}

\begin{abstract}
Notary is a general official authorized to make authentic deeds and other authorities stipulated in legislation. In addition to the duties and authority of Notaries as public officials, Notaries are also domiciled as subjects of personal law (natuurlijk person), namely having free will to carry out legal actions. The position of a Notary as the subject of this law, involves the establishment of a company, namely a Notary based as a board of directors in the form of a Limited Liability Company. Every company has a vision of sustainability and excellence, but in order to make it happen, financing is needed so that it requires the company to enter into a debt agreement. Consequently, when the debt is not able to be paid, the company led by the Notary is bankrupt and has been determined through the Decision of the Commercial Court which has permanent legal force. Thus, the status of a Notary becomes a Bankrupt Notary which results in sanctions stipulated in Law Number 2 Year 2014 concerning Amendments to Law Number 30 Year 2004 Notary Position, namely Notaries are dishonorably dismissed from their positions.
\end{abstract}

Keynote : Notary Bankcruptcy, Regulations of Notary

\begin{abstract}
ABSTRAK
Notaris adalah Pejabat umum yang berwenang untuk membuat akta autentik dan kewenangan lainnya yang diatur dalam peraturan perundang-undangan. Disamping tugas dan wewenang Notaris sebagai pejabat umum, Notaris juga berkedudukan sebagai subyek hukum pribadi (natuurlijk person) yaitu memiliki kehendak bebas untuk melakukan perbuatan hukum. Kedudukan Notaris sebagai subyek hukum ini melibatkan kegiatan pembentukan perusahaan yakni Notaris berkedudukan sebagai direksi dalam bentuk Perseroan Terbatas (PT). Setiap perusahaan memiliki visi keberlanjutan dan keunggulan, namun untuk mewujudkannya diperlukan pembiayaan sehingga mengharuskan PT untuk melakukan perjanjian utang piutang. Konsekuensinya ketika utang piutang tersebut tidak mampu dibayar maka perusahaan yang dipimpin oleh Notaris tersebut mengalami pailit dan telah ditetapkan melalui Putusan Pengadilan Niaga yang telah memiliki kekuatan hukum tetap. Dengan demikian status Notaris menjadi Notaris Pailit sehingga berakibat pada sanksi yang telah diatur dalam Undang-Undang Nomor 2 Tahun 2014 tentang Perubahan Atas Undang-Undang Nomor 30 Tahun 2004 Jabatan Notaris (UUJN) yaitu Notaris diberhentikan dengan tidak hormat dari jabatannya.
\end{abstract}

Kata kunci : Notaris pailit, Peraturan Jabatan Notaris

${ }^{1}$ Submission : 9-2-2019 I Review - 1: 12-2-2019| Review - 2: 6-3-2019 I Production : 12-3-2019 


\section{Pendahuluan}

Indonesia adalah negara hukum sebagaimana yang dinyatakan dalam Pasal 1 ayat (3) Undang-Undang Dasar Negara Republik Indonesia Tahun $1945 .^{2}$ Salah satu karakter negara hukum, ialah mempu mewujudkan tujuan hukum yaitu menegakkan keadilan, kepastian dan kemanfaatan bagi masyarakat Indonesia. Dalam mewujudkan tujuan hukum tersebut, tentunya negara dibantu oleh organ pemerintahan dan lembaga-lembaga negara, baik dari unsur yudikatif, legislatif dan eksekutif yang memiliki fungsi sebagaimana diatur dalam Undang-Undang Dasar Negara Republik Indonesia Tahun 1945, salah satunya mewujudkan kepastian hukum pada hukum pembuktian yang dilakukan oleh Notaris sebagai pejabat umum yang berwenang membuat akta autentik dan kewenangan lainnya berdasarkan Undang-Undang Nomor 2 Tahun 2014 tentang Perubahan Atas UndangUndang Nomor 30 Tahun 2004 Jabatan Notaris atau dapat disebut dengan (UUJN).

Notaris dalam perbuatan hukum pada satu sisi menjadi pejabat umum juga disisi lain sebagai subyek hukum orang pribadi (natuurlijk person), sehingga ruang lingkup perbuatan hukumnya luas, yaitu meliputi utang piutang, pinjam uang ke lembaga perbankan, mendirikan perusahaan yang kemudian mengalami pailit dan menjadi debitor pailit.

Pengertian debitor dalam Pasal 1 angka 3 Undang-Undang Nomor 30 Tahun 2007 tentang Kepailitan dan Penundaan Kewajiban Pembayaran Utang atau dapat disebut dengan (UUK PKPU), adalah orang yang mempunyai utang karena perjanjian atau Undang-Undang yang pelunasannya dapat ditagih di muka pengadilan. Selanjutnya Pasal 1131 dan Pasal 1132 Burgerlijk Wetboek (BW) yang mengatur tentang asas jaminan yang sifatnya accesoir dari perjanjian pokoknya. Makna dari dua kaedah hukum tersebut adalah seluruh

\footnotetext{
${ }^{2}$ Dalam Pasal 1 ayat (3) Undang-Undang Dasar Negara Republik Indonesia Tahun 1945 disebutkan bahwa "Negara Indonesia adalah Negara Hukum".
} 
harta orang yang berutang (debitor), baik yang ada maupun yang akan ada, menjadi jaminan untuk pelunasan utangnya. ${ }^{3}$

Konsekuensi kepailitan terhadap Notaris membawa akibat pemberhentian notaris, hal ini diatur dalam Pasal 9 ayat (1) huruf a UndangUndang Nomor 2 Tahun 2014 tentang Perubahan Atas Undang-Undang Nomor 30 Tahun 2004 tentang Jabatan Notaris (UUJN) yang menyatakan bahwa "Notaris diberhentikan sementara dari jabatannya karena: a. dalam proses pailit atau penundaan kewajiban pembayaran utang". 4 Kemudian dipertegas kembali pada Pasal 12 ayat (1) huruf a, UUJN menyatakan bahwa "Notaris diberhentikan dengan tidak hormat dari jabatannya oleh Menteri atas usul Majelis Pengawas Pusat apabila: a. dinyatakan pailit berdasarkan putusan pengadilan yang telah memperoleh kekuatan hukum tetap". 5

Kedua norma tersebut mengalami kekaburan atau vagenorm dan inkonsisten sehingga menimbulkan penafsiran ekstensif terhadap pemberhentian notaris yang mengalami pailit, mengingat Notaris yang pailit bukan merupakan badan hukum akan tetapi sebagai orang (natuurlijk person) membawa hak secara pribadi. Oleh karena itu perlunya dikaji kembali terhadap kaidah hukum Notaris Pailit.

Berdasarkan hasil penelusuran terhadap beberapa literatur yang telah dilakukan, maka penelitian yang membahas tentang Notaris Pailit cukup banyak telah dilakukan oleh para peneliti terdahulu, diantaranya seperti Kristiaan Litualy Talupoor dengan judul Thesisnya Rehabilitasi Debitor Pailit Terhadap Profesi Jabatan Notaris pada tahun 2014 yang dalam penelitiannya tersebut membahas tentang Pasal 12 huruf a UUJN yang menentukan bahwa apabila seorang notaris dinyatakan pailit dengan suatu putusan pernyataan pailit oleh pengadilan yang telah mempunyai kekuatan hukum tetap, maka notaris tersebut dapat diusulkan oleh MPP kepada menteri untuk

\footnotetext{
${ }^{3}$ Syamsudin M. Sinaga, Hukum Kepailitan Indonesia (Jakarta: Tatanusa, 2012). Hlm. 82

${ }^{4}$ Pasal 9 ayat (1) huruf a Undang-Undang Nomor 2 Tahun 2014 tentang Perubahan Atas Undang-Undang Nomor 30 Tahun 2004 tentang Jabatan Notaris

${ }_{5}$ Pasal 12 ayat (1) huruf a, Undang-Undang Nomor 2 Tahun 2014 tentang Perubahan Atas Undang-Undang Nomor 30 Tahun 2004 tentang Jabatan Notaris
} 
diberhentikan dengan tidak hormat. Setelah putusan pailit itu diberikan, tersedia upaya-upaya hukum yang dapat dilakukan oleh notaris terkait kepailitannya yaitu antara lain, gugat pembatalan putusan, pengurusan pemberesan, sampai upaya perdamaian dengan para kreditornya, apabila upaya-upaya ini berhasil, maka kepailitannya berakhir. ${ }^{6}$

Dengan berakhirnya kepailitan tersebut, maka dia dapat mengajukan permohonan rehabilitasi sebagaimana diatur dalam Pasal 215 UUK-PKPU UU 37 2004. Pada prinsipnya rehabilitasi tersebut telah mengangkat kepailitan dan juga dengan rehabilitasi maka kedudukan hukum dia telah dipulihkan, akan tetapi jabatannya sebagai notaris yang telah diberhentikan tidak turut direhabilitasi. UUJN tidak mengatur apakah dia dapat menjabat kembali ataukan tidak sebagai notaris. Pada titik inilah terjadi kekosongan hukum. Apakah dengan rehabilitasi maka dia dapat mengajukan untuk diangkat kembali dalam jabatan notaris ataukah tidak. Sekiranya dia dapat mengajukan kembali, dan kemudian permohonannya ditolak, apa upaya hukum yang dapat dilakukannya terkait penolakan itu. ${ }^{7}$

Kemudian Nur Aini Maulida dengan judul Thesisnya Pemberhentian Notaris Karena Pailit pada tahun 2011 yang dalam penelitiannya tersebut membahas tentang pemberhentian notaris dengan tidak hormat. Dalam Pasal 12 huruf a UUJN dirumuskan bahwa pemberhentian dengan tidak hormat terjadi karena 4 hal. Secara logis, keempat hal ini haruslah dapat didudukkan (dipandang) sebagai hal-hal yang memiliki kesetaraan yang menjadikan notaris (dapat) diberhentikan secara tidak hormat. Kesetaraan tersebut adalah pada kesetaraan nilai, dengan pengertian "dinyatakan pailit (a), berada di bawah pengampuan (b), melakukan perbuatan yang merendahkan kehormatan (c), dan melakukan pelanggaran berat terhadap kewajiban dan larangan jabatan (d)", haruslah dipandang sebagai hal yang setara, sehingga dapat sama-sama didudukkan sebagai sebab bagi pemberhentian secara tidak hormat

\footnotetext{
${ }^{6}$ Kristiaan Litualy Talupoor, "Rehabilitasi Debitor Pailit Terhadap Profesi Jabatan Notaris" (Universitas Airlangga, 2014). Hlm. 5

${ }^{7}$ Kristiaan Litualy Talupoor. HIm. 5
} 
seorang notaris. Jika tidak, tentu kita dapat menolak/ keberatan atas satu atau lain sebab yang ada di dalam pasal tersebut. ${ }^{8}$

Berdasarkan UU Kepailitan, urusan kepailitan adalah urusan utangpiutang yang tunduk pada Hukum Perjanjian. Utang-piutang adalah perbuatan hukum yang dibolehkan. Kepailitan itu sendiri adalah proses penyelesaian masalah utang-piutang. Secara sederhana tidak terlihat sesuatu yang memalukan, atau merendahkan jabatan notaris yang menjadikan kepailitan dapat disamakan atau disejajarkan dengan sebab lain yang dirumuskan di Pasal 12 huruf a UUJN. Akibat hukum dari adanya pernyataan pailit, menyebabkan si pailit kehilangan haknya untuk berbuat bebas terhadap kekayaannnya yang termasuk dalam kepailitan, begitu pula hak untuk mengurusnya, sejak tanggal putusan pailit diucapkan. Bagi Notaris tidak hanya kehilangan hak untuk mengurus harta kekayaannya saja, tetapi lebih dari itu dapat menyebabkan ia diberhentikan dengan tidak hormat dari jabatannya. Diberhentikan secara tidak hormat adalah akibat hukum yang tidak proporsional bagi seorang notaris yang dinyatakan pailit. Notaris tidak ada kaitannya dengan kepailitan. ${ }^{9}$

Mencermati dua penelitian terdahulu di atas, maka dapat dikatakan penelitian ini berbeda dengan penelitian tersebut, adapun unsur kebaruan dalam penelitian ini terletak pada kajian isu hukum masing-masing penelitian, yang dalam kajian ini membahas tentang penafsiran terhadap Notaris sebagai debitor Pailit serta korelasi Undang-Undang Kepailitan dan Undang-Undang Jabatan Notaris.

\section{Rumusan Masalah}

Berdasarkan penjelasan di atas, maka batasan masalah dalam penelitian ini, yaitu bagaimana penafsiran terhadap Notaris sebagai debitor Pailit serta bagaimana korelasi Undang-Undang Kepailitan dan Undang-Undang Jabatan Notaris?

\footnotetext{
${ }^{8}$ Nur Aini Maulida, "Pemberhentian Notaris Karena Pailit" (Universitas Airlangga, 2014). Hlm. 5

${ }^{9}$ Nur Aini Maulida. Hlm. 5
} 


\section{Tujuan Penelitian}

Tujuan penelitian ini yaitu untuk menganalisa penafsiran terhadap Notaris sebagai debitor Pailit serta mengkaji secara mendalam tentang korelasi Undang-Undang Kepailitan dan Undang-Undang Jabatan Notaris.

\section{Metodologi Penelitian}

Kajian ini didasarkan pada penelitian hukum normatif yaitu suatu penelitian yang dilakukan dengan mengkaji dan menganalisa bahan-bahan hukum dan isu-isu hukum yang terkait dengan permasalahan yang diteliti. Penelitian hukum dilakukan untuk memecahkan persoalan yang timbul, sedangkan hasil yang akan dicapai adalah berupa preskripsi mengenai apa yang seyogianya dilakukan untuk mengatasi persoalan tersebut. Demikian pula dalam tulisan ini melalui penelitian normatif dilakukan untuk mencari jawaban atas isu hukum Notaris Pailit.

Pendekatan yang digunakan dalam penelitian ini adalah pendekatan Undang-Undang (statute approach) dan pendekatan konseptual (conceptual approach). Pendekatan Undang-Undang (statute approach) dilakukan dengan menelaah semua Undang-Undang dan regulasi yang bersangkut paut dengan isu hukum yang sedang dianalisis. Pendekatan Undang-Undang bertujuan untuk mempelajari konsistensi dan kesesuaian antara suatu Undang-Undang dengan Undang-Undang lainnya atau antara Undang-Undang dengan UndangUndang Dasar Negara Republik Indonesia Tahun 1945 Negara Republik Indonesia atau antara regulasi dan Undang-Undang Jabatan Notaris serta Undang-Undang kepailitan.

Kemudian pendekatan konseptual merupakan pendekatan yang beranjak dari pandangan-pandangan dan doktrin-doktrin dalam ilmu hukum. Melalui penelaahan atas pandangan dan doktrin tersebut maka akan ditemukan ide yang melahirkan pengertian-pengertian hukum, konsep-konsep hukum dan asas-asas hukum yang relevan dengan isu hukum yang dihadapi dalam penelitian ini. Dalam penelitian ini akan digali konsep yang berkaitan dengan Penafsiran Ekstensif terhadap pemaknaan Notaris sebagai debitor Pailit dan 
Titik Singgung Undang-Undang Kepailitan dan Undang-Undang Jabatan Notaris.

Sumber hukum yang dipergunakan dalam penelitian ini terdiri dari Bahan Hukum Primer yaitu bahan hukum yang bersifat otoritatif, artinya bahan hukum tersebut mempunyai otoritas, yang terdiri dari peraturan perundang-undangan, catatan-catatan resmi atau risalah-risalah terkait dengan pembahasan suatu Undang-Undang. Dalam penelitian ini, perundangundangan sebagai bahan hukum primer adalah Undang-Undang Nomor 30 Tahun 2007 tentang Kepailitan dan Penundaan Kewajiban Pembayaran Utang (UUK PKPU) dan Undang-Undang Nomor 2 Tahun 2014 tentang Perubahan Atas Undang-Undang Nomor 30 Tahun 2004 Jabatan Notaris (UUJN).

Kemudian Bahan hukum sekunder, meliputi semua publikasi tentang hukum yang bukan merupakan dokumen resmi. Publikasi tentang hukum ini meliputi buku-buku teks, tesis, disertasi hukum, kamus hukum, komentar atas putusan pengadilan serta opini hukum dari para ahli yang dipublikasikan melalui jurnal, majalah atau internet/website.

Teknik Pengumpulan data yang akan digunakan dalam penelitian hukum ini adalah studi kepustakaan yang terbatas pada penggunaan dokumen dan bahan pustaka. Pengumpulan data dilakukan dengan cara mengumpulkan datadata tertulis yang berkaitan dengan masalah yang diteliti.

Analisa bahan hukum dalam penilitian ini menggunakan penalaran deduktif, yaitu menganalisa beberapa premis hukum dalam kajian ini untuk ditarik pada sebuah satu kesimpulan yang dapat menggambarkan jawaban dari rumusan masalah di atas.

\section{Hasil Penelitian dan Pembahasan}

\subsection{Penafsiran Notaris sebagai Debitor Pailit.}

Perjanjian dilandasi hak dan kewajiban untuk memenuhi prestasi bagi para pihak yang terlibat didalamnya. Ketika salah satu pihak tidak dapat memenuhi prestasi tersebut maka ia telah melakukan wanprestasi. Perlu diketahui bahwa wanprestasi adalah suatu keadaan menurut hukum 
perjanjian, dimana seseorang tidak memenuhi atau tidak melaksanakan prestasi sebagaimana telah ditetapkan dalam suatu perjanjian. Dalam hukum kepailitan disebut dalam hal debitor tidak mampu membayar utang (insolvent). ${ }^{10}$

Pada mekanisme hukum kepailitan, konsep utang sangat menentukan. ${ }^{11}$ Karena tanpa adanya utang, kepailitan kehilangan esensinya sebagai pranata hukum untuk melikuidasi harta kekayaan debitor guna membayar utang-utangnya kepada para kreditornya. ${ }^{12} \mathrm{Hal}$ tersebut secara tegas membedakan konsep utang dalam hukum perjanjian dan wanprestasi yang cukup diselesaikan dengan cara mengajukan gugatan wanprestasi, sedangkan konsep utang dalam hukum kepailitan merupakan suatu proses dimana seorang debitur yang mempunyai kesulitan keuangan untuk membayar utangnya dinyatakan pailit oleh pengadilan, dalam hal ini adalah pengadilan niaga, dikarenakan debitur tersebut tidak dapat membayar utangnya, Harta debitur dapat dibagikan kepada para kreditur sesuai dengan peraturan perundangan yang berlaku.

Robert L. Jordan sebagaimana dikutip dari Levinthal, tujuan utama dari hukum kepailitan digambarkan sebagai: "All bankruptcy law, however, no matter when or where devised and enacted, has at least two general objects in view. It aims, first, to secure and equitable division of the insolvent debtor's property among all his creditors, and, in the second place, to prevent on the part of the insolvent debtor conducts detrimental to the interest of his creditors. In other words, bankruptcy law seeks to protect the creditors, first, from one another and, secondly,

10 P.N.H. Simanjuntak, Pokok-Pokok Hukum Perdata Indonesia (Jakarta: Djambatan, 2009). Hlm. 339-340

${ }^{11}$ Menurut ketentuan Pasal 1 angka (6) UUK PKPU menyatakan utang adalah kewajiban yang dinyatakan atau dapat dinyatakan dalam jumlah uang, baik secara langsung maupun yang akan timbul di kemudian hari atau kontinjen, yang timbul karena perjanjian atau undang-undang dan yang wajib dipenuhi oleh debitor dan bila tidak dipenuhi memberi hak kepada kreditor untuk mendapat pemenuhannya dari harta kekayaan debitor. UUK PKPU mengartikan utang secara luas, sehingga utang bukan hanya yang timbul dari perjanjian pinjam-meminjam uang saja. (Sutan Remy Sjahdeini, Hukum Kepailitan: Memahami Undang-Undang No. 37 Tahun 2004 Tentang Kepailitan (Jakarta: Pustaka Utama Grafiti, 2010). Hlm.. 72-73).

${ }_{12}$ M. Hadi Shubhan, Hukum Kepailitan, Prinsip, Norma, Dan Praktik Di Peradilan (Jakarta: Kencana Prenada Media Group, 2008). Hlm. 34 
from their debtor. A third object the protection of the honest debtor from his creditors, by means of the discharge, is sought to be attained in some of the systems of bankruptcy, but this is by no means a fundamental feature of the law". 13

Seseorang baru dinyatakan pailit jika pihak kreditor yang berkepentingan atas piutang debitor mengajukan permohonan pernyataan pailit ke pengadilan niaga. Permohonan pernyataan pailit diajukan kepada Pengadilan Niaga, dengan syarat yang ditentukan dalam Pasal 2 ayat (1) jo. Pasal 8 ayat (4) UUK PKPU adalah:

\subsubsection{Ada dua atau lebih kreditor.}

Kreditor adalah orang yang mempunyai piutang karena perjanjian atau Undang-Undang yang dapat ditagih di muka pengadilan "Kreditor" di sini mencakup baik kreditor konkuren, kreditor separatis maupun kreditor preferen;

5.1.2. Ada utang yang telah jatuh waktu dan dapat ditagih.

Artinya adalah kewajiban untuk membayar utang yang telah jatuh waktu, baik karena telah diperjanjikan, karena percepatan waktu penagihannya sebagaimana diperjanjikan, karena pengenaan sanksi atau denda oleh instansi yang berwenang, maupun karena putusan pengadilan, arbiter, atau majelis arbitrase.

5.1.3. Kedua hal tersebut (adanya dua atau lebih kreditor dan adanya utang yang telah jatuh tempo dan dapat ditagih) dapat dibuktikan secara sederhana. ${ }^{14}$

\subsection{Penafsiran Gramatikal terhadap Notaris Pailit dalam UUJN}

Guna menemukan makna notaris pailit dalam UUJN maka perlu menggunakan suatu penafsiran atau interpretasi. Menurut pendapat Sudikno Mertokusumo dalam Ahmad Rifai, interpretasi atau penafsiran

\footnotetext{
${ }^{13}$ Robert L. Jordan, Bankruptcy (New York: Foundation Press, 1999). Hlm. 17

${ }^{14}$ Pasal 2 ayat (1) jo. Pasal 8 ayat (4) Undang-Undang 37 Tahun 2004 tentang Kepailitan dan Penundaan Kewajiban Pembayaran Utang
} 
merupakan salah satu metode penemuan hukum yang memberikan penjelasan gamblang tentang teks Undang-Undang, agar ruang lingkup kaidah dalam undang-undang tersebut dapat diterapkan pada peristiwa hukum tertentu. ${ }^{15}$

Keterkaitan dengan makna notaris pailit/notaris diberhentikan apabila dinyatakan pailit. Dalam UUJN tidak didefinisikan secara rinci mengenai notaris pailit tersebut, dikarenakan dalam UUK PKPU kriteria seorang debitor pailit ialah orang atau badan hukum, oleh karena itu diperlukan suatu penafsiran terhadap substansi pasal yang bersifat sumir tersebut.

Penafsiran atau interpretasi gramatikal adalah menafsirkan katakata dalam Undang-Undang sesuai dengan kaidah bahasa dan kaidah hukum tata bahasa. Interpretasi gramatikal ini merupakan upaya yang tepat untuk mencoba memahami suattu teks aturan perundang-undangan. Metode intepretasi ini disebut juga metode interpretasi objektif. Biasanya intepretasi gramatikal dilakukan oleh hakim bersamaan dengan intepretasi logis, yaitu memaknai berbagai aturan hukum yang ada melalui penalaran hukum untuk diterapkan terhadap teks yang kabur atau kurang jelas. ${ }^{16}$

Penafsiran terhadap Pasal 9 ayat (1) huruf a dan Pasal 12 ayat (1) huruf a UUJN yang menyatakan bahwa:

5.2.1. Notaris diberhentikan sementara dari jabatannya karena: a. dalam proses pailit atau penundaan kewajiban pembayaran utang" (Pasal 9 ayat (1) huruf a UUJN).

5.2.2. Notaris diberhentikan dengan tidak hormat dari jabatannya oleh Menteri atas usul Majelis Pengawas Pusat apabila: a. dinyatakan pailit berdasarkan putusan pengadilan yang telah memperoleh kekuatan hukum tetap" (Pasal 12 ayat (1) huruf a UUJN).

\footnotetext{
${ }^{15}$ Ahmad Rifai, Penemuan Oleh Hakim Dalam Perspektif Hukum Progresif (Jakarta: Sinar Grafika, 2014). Hlm. 36

${ }^{16}$ Ahmad Rifai. Hlm. 63
} 
Pokok pikiran utama dalam Pasal 9 dan Pasal 12 UUJN ialah Notaris diberhentikan sementara dari jabatannya karena: a. dalam proses pailit" dan Notaris diberhentikan dengan tidak hormat dari jabatannya apabila: a. dinyatakan pailit berdasarkan putusan pengadilan”. Ketentuan pasal tersebut menimbulkan kekaburan, sehingga menimbulkan beberapa pertanyaan seperti apakah Notaris sebagai pejabat umum dapat dinyatakan pailit, dalam hal apa, Notaris dijatuhkan Pailit serta mengapa Notaris pailit diberhentikan secara tidak hormat.

Berdasarkan pada pertanyaan tersebut, akibatnya timbul suatu keragu-raguan dalam benak praktisi, akademisi dan hakim dalam menerapkan bidang hukum apa (kepailitan atau kode etik notaris) yang digunakan manakala terjadi kepailitan terhadap Notaris.

Berpijak pada pengertian Notaris dalam Pasal 1 angka 1 UUJN menyatakan bahwa "Notaris adalah pejabat umum yang berwenang untuk membuat akta autentik dan memiliki kewenangan lainnya sebagaimana dimaksud dalam Undang-Undang ini atau berdasarkan Undang-Undang lainnya”. Definisi yang diberikan oleh UUJN ini juga merujuk pada tugas dan wewenang yang dijalankan oleh notaris. Artinya notaris memiliki tugas sebagai pejabat umum dan memiliki wewenang untuk membuat akta otentik serta kewenangan lainnya yang diatur oleh UUJN. $^{17}$

Lebih lanjut Pasal 1868 BW juga menyebutkan bahwa Notaris sebagai pejabat umum hal demikian dirumuskan sebagai berikut "suatu akta otentik ialah suatu akta yang dibuat dlm bentuk yg ditentukan UU oleh/dihadapan pejabat umum yg berwenang untuk itu di tempat akta itu dibuat". Dengan demikian wewenang pengesahan suatu akta terhadap perbuatan hukum hanya dapat dibuat dihadapan pejabat umum yaitu notaris, akan tetapi pejabat umum belum tentu juga berprofesi sebagai Notaris.

${ }^{17}$ Abdhul Ghofur, Lembaga Kenotariatan Indonesia (Yogyakarta: UII Press, 2009). Hlm. 
Pembatasan terhadap definisi pejabat umum dijelaskan dalam pendapat sebagai berikut Pejabat Umum merupakan suatu jabatan yang disandang atau diberikan kepada mereka yang diberi wewenang oleh aturan hukum dalam pembuatan akta otentik. Notaris sebagai Pejabat Umum kepadanya diberikan kewenangan untuk membuat akta otentik. Oleh karena itu Notaris sudah pasti Pejabat Umum, tapi Pejabat Umum belum tentu Notaris, karena Pejabat Umum dapat disandang pula oleh Pejabat Pembuat Akta Tanah (PPAT) atau Pejabat Lelang. ${ }^{18}$

Pasal 1 angka 3 dan 4 UUK PKPU menyatakan "Debitor adalah orang yang mempunyai utang karena perjanjian atau undang-undang yang pelunasannya dapat ditagih di muka pengadilan". Debitor pailit adalah debitor yang sudah dinyatakan pailit dengan putusan Pengadilan”. Dalam hal ini, pernyataan pemberhentian notaris sementara dan pemberhentian notaris secara tidak hormat apabila dinyatakan pailit, tidak ada ada keterkaitan dengan aturan dalam UUJN dan Kode Etik Notaris sehingga Notaris Pailit disetarakan dengan perbuatan tercela dan tindak pidana atau melanggar undang-undang, seolah-olah Notaris yang mengalami Pailit telah melakukan perbuatan tercela dan pelanggaran terhadap undang-undang. Dengan demikian penormaan pemberhentian notaris apabila pailit tidak sesuai dengan asas-asas hukum kepailitan, yaitu asas keseimbangan, asas kelangsungan Usaha, asas keadilan dan asas integrasi, sebab Notaris bukan Pelaku Usaha dalam hal ini bukan badan usaha yang berbadan hukum maupun tidak berbadan hukum.

\subsection{Korelasi Undang-Undang Kepailitan dan Undang-Undang Jabatan Notaris.}

Kepailitan terjadi dikarenakan adanya utang debitor yang di dalam utang tersebut kadangkala terdapat suatu jaminan, Pasal 1131 BW menyatakan bahwa "semua kebendaan si berutang, baik yang bergerak

\footnotetext{
${ }^{18}$ jimlyschool.com, "Notaris," 2016, http://www.jimlyschool.com/read/analisis/384/notarisopenbare-amtbtenaren-syafran-sofyan/.
} 
maupun yang tidak bergerak, baik yang sudah ada maupun yang baru akan ada di kemudian hari, menjadi tanggungan untuk segala perikatan perseorangan". Pasal $1131 \mathrm{BW}$ tersebut. ${ }^{19}$ Mengandung asas schuld dan haftung, bahwa setiap orang bertanggung jawab terhadap utangnya, dengan menyediakan seluruh kekayaannya, jika perlu dijual untuk melunasi utangnya. Pasal 1234 BW menyatakan bahwa tiap-tiap perikatan adalah untuk memberikan sesuatu, berbuat sesuatu, atau tidak berbuat sesuatu.

Sri Soedewi M. Sofwan menerjemahkan istilah hukum perikatan (verbitenissenrecht) itu dengan perutangan. Menurutnya perutangan itu merupakan hubungan hukum yang atas dasar itu seseorang dapat mengharapkan suatu prestasi dari seseorang yang lain jika perlu dengan perantaraan hakim. $^{20}$

Tujuan utama dari hukum kepailitan meliputi:

"All bankruptcy law, however, no matter when or where devised and enacted, has at least two general objects in view. It aims, first, to secure and equitable division of the insolvent debtor's property among all his creditors, and, in the second place, to prevent on the part of the insolvent debtor conducts detrimental to the interest of his creditors. In other words, bankruptcy law seeks to protect the creditors, first, from one another and, secondly, from their debtor. A third object the protection of the honest debtor from his creditors, by means of the discharge, is sought to be attained in some of the systems of bankruptcy, but this is by no means a fundamental feature of the law". 21

Syarat pengajuan pailit terhadap debitor-debitor tertentu diatur dalam Pasal 2 UUK PKPU sebagai berikut:

5.3.1. Dalam hal Debitor adalah bank, permohonan pernyataan pailit hanya dapat diajukan oleh Bank Indonesia.

19 Ivida Dewi Amrih Suci and Herowati Poesoko, Hak Kreditor Separatis Dalam Mengeksekusi Benda Jaminan Debitor Pailit (Yogyakarta: LaksBang PRESSindo, 2011). Hlm. 16

${ }^{20}$ Sri Soedewi Masjchoen Sofwan, Hukum Perdata-Hukum Perutangan (Yogyakarta: Bagian A, Seksi Hukum Perdata UGM, 1980). Hlm. 1

${ }^{21}$ Robert L. Jordan, Bankruptcy. Hlm. 17 
5.3.2. Dalam hal Debitor adalah Perusahaan Efek, Bursa Efek, Lembaga Kliring dan Penjaminan, Lembaga Penyimpanan dan Penyelesaian, permohonan pernyataan pailit hanya dapat diajukan oleh Badan Pengawas Pasar Modal.

5.3.3. Dalam hal Debitor adalah Perusahaan Asuransi, Perusahaan Reasuransi, Dana Pensiun, atau Badan Usaha Milik Negara yang bergerak di bidang kepentingan publik, permohonan pernyataan pailit hanya dapat diajukan oleh Menteri Keuangan.

Pasal tersebut merupakan penegasan bahwa debitor disamping bertindak secara pribadi (orang) juga badan hukum, namun tidak disebutkan Jabatan Notaris sebagai debitor. Kepailitan meliputi seluruh kekayaan Debitor pada saat putusan pernyataan pailit diucapkan serta segala sesuatu yang diperoleh selama kepailitan yang diatur dalam Pasal 22 UUK PKPU Namun tidak berlaku dan dikecualikan untuk kekayaan debitor, yang meliputi:

5.3.1. Benda, termasuk hewan yang benar-benar dibutuhkan oleh Debitor sehubungan dengan pekerjaannya, perlengkapannya, alat-alat medis yang dipergunakan untuk kesehatan, tempat tidur dan perlengkapannya yang dipergunakan oleh Debitor dan keluarganya, dan bahan makanan untuk 30 (tiga puluh) hari bagi Debitor dan keluarganya, yang terdapat di tempat itu.

5.3.2. Segala sesuatu yang diperoleh Debitor dari pekerjaannya sendiri sebagai penggajian dari suatu jabatan atau jasa, sebagai upah, pensiun, uang tunggu atau uang tunjangan, sejauh yang ditentukan oleh Hakim Pengawas; atau

5.3.3. Uang yang diberikan kepada Debitor untuk memenuhi suatu kewajiban memberi nafkah menurut Undang-Undang. 
Selama ini secara normatif disebutkan dalam UUJN bahwa Notaris yang pailit berdasarkan putusan pengadilan akan diberhentikan. Maknanya bahwa pembentuk Undang-Undang menghendaki dan menganggap bahwa kepailitan yang di alami Notaris merupakan pelanggaran UUJN. Pemaknaan Notaris Pailit dalam Pasal 9 juncto Pasal 12 UUJN dalam penafsiran gramatikal bersifat sumir dan tidak jelas atau kabur (vagenorm) serta abigu. Definisi tidak boleh dinyatakan ke dalam bahasa yang samar-samar (kabur), haruslah lebih jelas daripada istilah yang didefinisikan. Pelanggaran terhadap aturan ini mengakibatkan kesalahan yang disebut figurative definition (definisi secara klas) atau absure definition (definisi yang samar-samar). Tujuannya ialah menemukan definisi dalam Undang-Undang secara ontologi membahas Hakekat digunakan dalam mencari suatu kebenaran terhadap pengertian Notaris Pailit.

Sifat sumir dan ambiguitas ini dapat di interpretasikan makna Notaris dalam UUJN dan BW. Pasal 1 angka 1 UUJN menyatakan bahwa Notaris adalah pejabat umum yang berwenang untuk membuat akta autentik dan memiliki kewenangan lainnya sebagaimana dimaksud dalam Undang-Undang ini atau berdasarkan Undang-Undang lainnya. Apabila ditilik kembali dalam Pasal 1868 Kitab Undang-Undang Hukum Perdata (KUHPerdata) menyatakan bahwa Notaris sebagai pejabat umum hal demikian dirumuskan sebagai berikut "suatu akta otentik ialah suatu akta yang dibuat dlm bentuk yg ditentukan Undang-Undang oleh/dihadapan pejabat umum yang berwenang untuk itu di tempat akta itu dibuat".

Apabila direnungkan kembali tidak ada titik singgung antara UUK PKPU dengan UUJN, sehingga tidak tercapai kepastian hukum. Menurut pendapat Ronald Dworkin mengatakan bahwa: "We live in and by law..., How can the law command when the law books are silent or unclear or 
ambiguous?". 22 Bahwa dalam situasi dimana terdapat ketidak jelasan peraturan, maka akan menyebabkan hukum tidak bisa mengatur sebagaimana mestinya. Terkait dengan kepastian hukum, Gustav Radbruch dalam Ahmad Ali mengemukakan tentang tiga nilai dasar (Grundwerten) yaitu: Keadilan (Gerechtigkeit), kemanfaatan (Zweckmaeszigkeit) dan kepastian hukum (Rechtssicherkeit), yang satu sama lainnya tidak selalu harmonis, melainkan saling berhadapan, bertentangan dan berketegangan (spannungsverhaeltnis). ${ }^{23}$

\section{Kesimpulan}

6.1. Penafsiran terhadap Pasal 9 ayat (1) huruf a dan Pasal 12 ayat (1) huruf a UUJN yang menyatakan bahwa Notaris diberhentikan sementara dari jabatannya karena: a. dalam proses pailit atau penundaan kewajiban pembayaran utang" (Pasal 9 ayat (1) huruf a UUJN) serta Notaris diberhentikan dengan tidak hormat dari jabatannya oleh Menteri atas usul Majelis Pengawas Pusat apabila: a. dinyatakan pailit berdasarkan putusan pengadilan yang telah memperoleh kekuatan hukum tetap" (Pasal 12 ayat (1) huruf a UUJN). Pokok pikiran utama dalam Pasal 9 dan Pasal 12 UUJN ialah Notaris diberhentikan sementara dari jabatannya karena: a. dalam proses pailit" dan Notaris diberhentikan dengan tidak hormat dari jabatannya apabila: a. dinyatakan pailit berdasarkan putusan pengadilan". Ketentuan pasal tersebut menimbulkan kekaburan, sehingga menimbulkan beberapa pertanyaan seperti apakah Notaris sebagai pejabat umum dapat dinyatakan pailit, dalam hal apa, Notaris dijatuhkan Pailit serta mengapa Notaris pailit diberhentikan secara tidak hormat. Pembatasan terhadap definisi pejabat umum dijelaskan dalam pendapat sebagai berikut Pejabat Umum merupakan suatu jabatan yang disandang

${ }^{22}$ Patrick Nerhot, Law Interpretation and Reality (AA Dordrecht Netherlands: Kluwer Academic Publisher, 1990). Hlm. 194

23 Ahmad Ali, Menguak Teori Hukum (Legal Theory) Dan Teori Peradilan (Judicialprudence);Termasuk Interpretasi Undang-Undang (Legisprudence) Vol. 1 Pemahaman Awal (Jakarta: Kencana Prenada Media Group, 2010). Hlm. 292 
atau diberikan kepada mereka yang diberi wewenang oleh aturan hukum dalam pembuatan akta otentik. Notaris sebagai Pejabat Umum kepadanya diberikan kewenangan untuk membuat akta otentik. Oleh karena itu Notaris sudah pasti Pejabat Umum, tapi Pejabat Umum belum tentu Notaris, karena Pejabat Umum dapat disandang pula oleh Pejabat Pembuat Akta Tanah (PPAT) atau Pejabat Lelang.

6.2. Bahwa pengaturan Notaris Pailit dalam UUJN dan UUK PKPU tidak ada korelasi, dikarenakan pemaknaan Notaris Pailit mengalami kekaburan (vagenorm), dimana substansi hukum kepailitan menyatakan bahwa beberapa hal yang tidak dapat dipailitkan adalah segala sesuatu yang diperoleh Debitor dari pekerjaannya sendiri sebagai penggajian dari suatu jabatan atau jasa. Pengaturan Notaris pailit dalam UUJN Pasal 9 dan Pasal 12 bersifat kabur, ambiguitas dan inkonsisten. 


\section{DAFTAR PUSTAKA}

\section{Buku}

Abdhul Ghofur. Lembaga Kenotariatan Indonesia. Yogyakarta: UII Press, 2009.

Ahmad Rifai. Penemuan Oleh Hakim Dalam Perspektif Hukum Progresif. Jakarta: Sinar Grafika, 2014.

Ivida Dewi Amrih Suci, and Herowati Poesoko. Hak Kreditor Separatis Dalam Mengeksekusi Benda Jaminan Debitor Pailit. Yogyakarta: LaksBang PRESSindo, 2011.

Kristiaan Litualy Talupoor. "Rehabilitasi Debitor Pailit Terhadap Profesi Jabatan Notaris.” Universitas Airlangga, 2014.

M. Hadi Shubhan. Hukum Kepailitan, Prinsip, Norma, Dan Praktik Di Peradilan. Jakarta: Kencana Prenada Media Group, 2008.

Nur Aini Maulida. "Pemberhentian Notaris Karena Pailit." Universitas Airlangga, 2014.

P.N.H. Simanjuntak. Pokok-Pokok Hukum Perdata Indonesia. Jakarta: Djambatan, 2009.

Patrick Nerhot. Law Interpretation and Reality. AA Dordrecht Netherlands: Kluwer Academic Publisher, 1990.

Robert L. Jordan. Bankruptcy. New York: Foundation Press, 1999.

Sri Soedewi Masjchoen Sofwan. Hukum Perdata-Hukum Perutangan. Yogyakarta: Bagian A, Seksi Hukum Perdata UGM, 1980.

Sutan Remy Sjahdeini. Hukum Kepailitan: Memahami Undang-Undang No. 37 Tahun 2004 Tentang Kepailitan. Jakarta: Pustaka Utama Grafiti, 2010.

Syamsudin M. Sinaga. Hukum Kepailitan Indonesia. Jakarta: Tatanusa, 2012.

\section{Artikel Jurnal}

Ahmad Ali. Menguak Teori Hukum (Legal Theory) Dan Teori Peradilan (Judicialprudence);Termasuk Interpretasi Undang-Undang 
(Legisprudence) Vol. 1 Pemahaman Awal. Jakarta: Kencana Prenada Media Group, 2010.

\section{Peraturan Perundang-Undangan}

Undang-Undang Nomor 30 Tahun 2007 tentang Kepailitan dan Penundaan Kewajiban Pembayaran Utang (UUK PKPU).

Undang-Undang Nomor 2 Tahun 2014 tentang Perubahan Atas UndangUndang Nomor 30 Tahun 2004 Jabatan Notaris (UUJN).

\section{Media Online}

jimlyschool.com. "Notaris," 2016.

http://www.jimlyschool.com/read/analisis/384/notaris-openbareamtbtenaren-syafran-sofyan/. 